\title{
Editorial: The longitude of technoscientific progress
}

\author{
Akhlesh Lakhtakia \\ Editor-in-Chief
}

For eight centuries prior to the expulsion of the Moors from Spain, science and technology thrived in an Islamic setting. From my optical perch, I marvel at Ya'qūb ibn Ishāa al-Kindī’s construction of every point on the surface of a luminous object emitting light omnidirectionally, Abū 'Alī al-Hasan ibn al-Hasan ibn al-Haytham's correct postulation of the way our eyes see, and Abu Sa'd al-'Ala' ibn Sahl's geometrical deduction of a law that is commonly associated today with the name of Willebrord van Snel van Roijen. Concurrent advances in other branches of science as well as in mathematics occurred throughout the realm of the Caliphs - atop earlier accomplishments from Italy, Greece, Egypt, Iraq, Persia, and India. At the same time, science and technology were flourishing in China and, to a lesser extent, in India. Balancing China in the east and Spain in the west, the longitude of technoscientific progress probably passed through Syria during most of those centuries.

Quite suddenly, however, the technoscientific edifice froze and even began to crumble in the Islamic setting. Technoscientific vitality began to wane in China and India as well. The longitude shifted westward to pass through eastern France and western Germany in the 18th and 19th centuries, as technoscientific progress began to occur at an increasingly rapid pace from Ireland in the west to Ukraine in the east. Nation after nation, particularly in Western Europe, set up scientific academies and technical schools where knowledge was both created by, and disseminated to, an ever-increasing group of people.

The United States of America grew into a technoscientific colossus during the 20th century. Western Europe did not diminish in importance, however, and the Soviet Union was a formidable rival to the technoscientific dominance of the USA. Japan too became a cradle of technoscientific progress. The longitude of technoscientific progress moved westward still, perhaps traversing some of the Atlantic seaboard states of the USA.

Nary a week passes nowadays when I do not read of China's rising might in the technoscientific world. ${ }^{1}$ The year in which the annual production of research papers from Chinese addresses will overtake that from US addresses is often predicted, not only in policy documents of institutions such as the Royal Society ${ }^{2}$ but also in daily newspapers and news websites. The earliest year predicted is $2013,{ }^{3}$ just two years away. Often, such reports do not fail to mention that the quality of Chinese research is not quite up to the standards of research in the USA and Western Europe, perhaps to reassure certain people afraid of the scientific tide receding from their countries. Given that research in India is also expanding rapidly though not yet as fast as in China, ${ }^{4,5}$ and given that Islamic countries are witnessing a renaissance in research as well, ${ }^{6}$ now the longitude of technoscientific progress probably passes through Japan.

Or, has that longitude not only frozen in place but also started to fade? Europe and Japan have not declined in technoscientific innovation, and neither has the USA. Add Australia, New Zealand, South Africa, Brazil, Argentina, and Canada to the mix. As an increasingly larger fraction of the global population becomes technoscientifically literate and imbued with what Jawaharlal Nehru called the "scientific temper,"7 the longitude of technoscientific progress is no longer a meaningful concept. Technoscientific progress is occurring worldwide.

I have no doubt that we live in the best of times so far in human history. The technoscientific revolutions originating during the last six decades have completely connected the planet. Even from the remote islands of Kiribati does a friend of mine skype with me. Dictators, not to mention democratically elected politicians, have begun to quake before the voices of their

$1934-2608 / 2011 / \$ 25.00$ @ 2011 SPIE 
people organized through social media powered by the fruits of technoscientific research. Rapid and global mobility of people and ideas shows up racial taxonomy as a canard. Research, design, and manufacturing are being globalized, and many a product is released simultaneously in different parts of the world. To be sure, there are winners and losers, but an increasingly larger segment of the global population sees its well-being in higher education, especially science and technology.

We do have to tackle new problems, many of our own making. But, in my optimistic view, every human brain is better than a computer. We have about 7 billion brains - an awe-inspiring resource to solve our problems and assure our future. We also have enough resources, globally, to feed, house and educate every one of the bodies housing those brains. Our innate curiosity and ingenuity guarantee that satisfactory answers will continue to emerge for contemporary major problems: pollution, sustainability, energy consumption, infectious diseases, and so on.

Though humans have never lived better than now, I am confident that the future shall be even better.

\section{References}

1. A. Plume, "Tipping the balance: The rise of China as a science superpower," Research Trends (Scopus), Issue 22, pp. 11-12 (2011).

2. Royal Society, Knowledge, Networks and Nations: Global Scientific Collaboration in the 21st Century, Policy Document 03/11 (2011).

3. D. Shukman, "China 'to overtake US on science' in two years," BBC News (28 March 2011), http://www.bbc.co.uk/news/science-environment-12885271.

4. R. N. Kostoff, M. E. Eriggs, R. L. Rushenberg, C. A. Eowles, S. Bhattacharya, D. Johnson, A. S. Icenhour, K. Nikodym, R. B. Barth, S. Dodbele, and M. Pecht, "Assessment of science and technology literature of China and India as reflected in the SCI/SSCI," Curr. Sci. 93, 1088-1092 (2007).

5. M. Madan, G. Chandrasekar and S. Arunachalam, "Highly cited papers from India and China," Curr. Sci. 99, 738-749 (2010).

6. A. Plume, "A rebirth of science in Islamic countries?," Research Trends (Scopus), Issue 21, pp. 6-8 (2011).

7. B. Parekh, "Nehru and the national philosophy of India," Economic \& Political Weekly 26(1/2), 35-48 (1991) http://www.jstor.org/stable/4397189. 